Jurnal Ilmu Ilmu Agribisnis: Journal of Agribusiness Science, 9(2), Mei 2021

\title{
ANALISIS SISTEM AGRIBISNIS USAHA TERNAK KAMBING SABURAI PADA KOPERASI PRODUSEN PETERNAK (KPP) SABURAI MANDIRI DI KECAMATAN GISTING KABUPATEN TANGGAMUS
}

\author{
(Agribusiness System Analysis of Saburai Goat Livestock at Saburai Mandiri Producer Livestock \\ Cooperative (KPP) in Gisting Sub-District of Tanggamus District)
}

Panji Hirawan, Dyah Aring Hepiana Lestari, Eka Kasymir

Jurusan Agribisnis, Fakultas Pertanian, Universitas Lampung, Jl. Prof. Dr. Soemantri Brodjonegoro No. 1

Bandar Lampung 35145, e-mail: dyah.aring@fp.unila.ac.id

\begin{abstract}
This research aims were to determine the procurement system saburai goat livestock business production facilities, saburai goat livestock business income, saburai goat production cost, saburai goat marketing channel, saburai goat agribusiness system supporting services and the role of Saburai Mandiri Producer Livestock Cooperative (KPP) in the saburai goat agribusiness system. The research was taken a case study at KPP Saburai Mandiri located in Gisting Sub-District Tanggamus District. The procurement of saburai goat livestock business production facilities has been right with an accuracy level of 83,96 percent. Saburai goat livestock business average income was Rp22.563.979,21 per year. Saburai goat production cost was Rp31.248,68 per kg. Saburai goat marketing channel was divided into two types product which each has four marketing channels. Saburai goat agribusiness system supporting services were financial institutions (banks), extension agencies, government policies, farmer/livestock groups, transportation facilities, information and communication technology and markets. The role of KPP Saburai Mandiri in saburai goat livestock agribusiness system was already good enough.
\end{abstract}

Key words: Agribusiness, cooperative, livestock business, saburai goat.

\section{PENDAHULUAN}

Subsektor peternakan memiliki peranan penting dalam menyediakan produksi daging, telur, dan susu untuk memenuhi permintaan masyarakat yang saat ini semakin tinggi, sehingga menjadikan usaha ternak di Indonesia memiliki peluang usaha yang cukup besar, salah satunya usaha ternak kambing. Menurut Peraturan Menteri Pertanian Nomor 57/Permentan/OT.140/10/2006, pengembangan usaha ternak kambing memiliki prospek yang baik, karena di samping memenuhi kebutuhan daging di dalam negeri, kambing juga memiliki peluang sebagai komoditas ekspor.

Provinsi Lampung merupakan daerah dengan populasi kambing terbesar di Pulau Sumatera yang mencapai 1,4 juta ekor (Ditjen Peternakan dan Keswan 2019). Meskipun demikian, pertumbuhan populasi kambing di Provinsi Lampung masih berjalan lambat yaitu tidak lebih dari empat persen setiap tahunnya, sehingga masih perlu ditingkatkan.

Upaya meningkatkan laju pertumbuhan populasi kambing di Provinsi Lampung perlu dilakukan di daerah yang memiliki potensi yang cukup baik untuk pengembangan usaha ternak ini, salah satunya adalah Kabupaten Tanggamus yang merupakan salah satu daerah dengan populasi kambing terbesar di Provinsi Lampung.

Kabupaten Tanggamus juga merupakan wilayah sumber bibit kambing khas Provinsi Lampung, yaitu kambing saburai. Namun, populasi kambing saburai di Kabupaten Tanggamus saat ini masih sangat rendah. Berdasarkan Dinas Peternakan Kabupaten Tanggamus (2015), persentase tertinggi populasi kambing saburai jika dibandingkan dengan total seluruh populasi kambing di Kabupaten Tanggamus pada tahun 2012, yaitu sebesar 23,16 persen, sehingga belum sesuai dengan Peraturan Menteri Pertanian Nomor 19/Permentan/OT.140/3/2012 yang menyatakan persentase rumpun tertentu yang ditetapkan sebagai sumber daya genetik dalam wilayah sumber bibit tidak boleh kurang dari 80 persen. Oleh karena itu, perlu dilakukan upaya untuk peningkatan populasi kambing saburai dengan memperhatikan kinerja sistem agribisnis kambing saburai dari hulu ke hilir.

Sistem agribisnis usaha ternak kambing saburai memerlukan peran berbagai badan usaha untuk 
turut mengelola usaha ternak ini, misalnya koperasi. Terdapat koperasi di Kabupaten Tanggamus yang turut mengelola dan fokus terhadap pengembangan usaha ternak kambing saburai, yaitu KPP Saburai Mandiri yang didirikan untuk membantu para peternak kambing saburai menghadapi berbagai permasalahan dalam usaha ternak kambing saburai, yaitu terbatasnya modal yang dimiliki, harga kambing saburai yang fluktuatif, dan pemasaran kambing saburai yang masih cukup sulit.

Berdasarkan latar belakang tersebut, maka penelitian ini bertujuan untuk mengetahui pengadaan sarana produksi usaha ternak kambing saburai, pendapatan usaha ternak kambing saburai, harga pokok produksi kambing saburai, saluran pemasaran kambing saburai, jasa layanan penunjang yang mendukung agribisnis kambing saburai dan peran KPP Saburai Mandiri dalam sistem agribisnis kambing saburai anggota koperasi.

\section{METODE PENELITIAN}

Penelitian ini menggunakan metode studi kasus pada KPP Saburai Mandiri di Kecamatan Gisting Kabupaten Tanggamus. Lokasi penelitian dipilih secara sengaja (purposive) dengan pertimbangan koperasi tersebut merupakan koperasi aktif yang beranggotakan para peternak kambing saburai. Data yang dikumpulkan dalam penelitian ini adalah data primer yang diperoleh dari hasil wawancara dan data sekunder yang diperoleh dari KPP Saburai Mandiri, publikasi, instansi terkait, dan pustaka lainnya.

Responden pada penelitian ini adalah seluruh anggota KPP Saburai Mandiri yang berjumlah 40 orang. Hal tersebut dikarenakan jumlah populasi anggota koperasi dalam penelitian ini kurang dari 100, sehingga jumlah sampelnya diambil secara keseluruhan (Arikunto 2012). Selanjutnya, responden dalam analisis saluran pemasaran diambil menggunakan metode snowball sampling.

Analisis deskriptif kualitatif dan deskriptif kuantitatif digunakan untuk mengetahui pengadaan sarana produksi usaha ternak kambing saburai anggota koperasi. Pengadaan sarana produksi usaha ternak kambing anggota KPP Saburai Mandiri akan dianalisis menggunakan metode 6 tepat, yaitu tepat kuantitas, tepat tempat, tepat jenis, tepat kualitas, tepat harga, dan tepat waktu dengan membandingkan kriteria ketepatan terhadap kenyataan sebenarnya yang terjadi dalam usaha ternak kambing saburai anggota KPP Saburai Mandiri. Apabila tepat, maka akan diberi bobot nilai satu (1) dan apabila tidak tepat, maka akan diberi bobot nilai nol (0). Selanjutnya akan dihitung tingkat ketepatan pengadaan sarana produksi usaha ternak kambing saburai anggota KPP Saburai Mandiri dengan rumus berikut :

Tingkat ketepatan $=\frac{\text { Bobot nilai diperoleh }}{\text { Bobot nilai maksimum }} \times 100 \% \ldots . . .(1)$

Hasil perhitungan tingkat ketepatan pengadaan sarana produksi usaha ternak kambing saburai anggota KPP Saburai Mandiri selanjutnya dibandingkan dengan tabel kriteria analisis deskriptif persentase yang tersaji pada Tabel 1 .

Metode analisis deskriptif kuantitatif digunakan untuk menghitung pendapatan usaha ternak kambing saburai dan harga pokok produksi kambing saburai anggota KPP Saburai Mandiri. Analisis pendapatan usaha ternak kambing saburai secara matematis dirumuskan sebagai berikut (Soekartawi 2000) :

$\pi=\mathrm{TR}-\mathrm{TC}$

keterangan :

$\begin{array}{ll}\pi & =\text { pendapatan (Rp/tahun) } \\ \mathrm{TR} & =\text { penerimaan total }(\mathrm{Rp} / \mathrm{tahun}) \\ \mathrm{TC} & =\text { biaya total }(\mathrm{Rp} / \mathrm{tahun})\end{array}$

Selain biaya bibit, seluruh biaya dalam usaha ternak kambing saburai dihitung menggunakan alokasi joint cost dengan metode nilai jual relatif, dikarenakan anggota KPP Saburai Mandiri tidak hanya membudidayakan kambing saburai saja melainkan juga kambing non saburai, yaitu kambing rambon, kambing peranakan etawa (PE), dan kambing boerawa.

Metode analisis yang digunakan untuk menghitung harga pokok produksi kambing saburai, yaitu dengan metode perhitungan atas biaya total (full costing) dengan membagi total harga pokok produksi terhadap total produksi kambing saburai. Pada Tabel 2 disajikan metode perhitungan harga pokok produksi usaha ternak kambing saburai anggota KPP Saburai Mandiri.

Tabel 1. Kriteria analisis deskriptif persentase

\begin{tabular}{cll}
\hline No & Persentase & \multicolumn{1}{c}{ Kriteria } \\
\hline 1. & $75 \%-100 \%$ & Sangat Baik \\
2. & $50 \%-75 \%$ & Baik \\
3. & $25 \%-50 \%$ & Cukup Baik \\
4. & $1 \%-25 \%$ & Kurang Baik \\
\hline \multicolumn{2}{l}{ Sumber : } &
\end{tabular}


Tabel 2. Perhitungan harga pokok produksi kambing saburai anggota KPP Saburai Mandiri

\begin{tabular}{lcc}
\hline \multicolumn{1}{c}{ Uraian } & Satuan & Nilai \\
\hline Penerimaan Produksi & $\mathrm{kg}$ & $\mathrm{A}$ \\
Biaya Tunai & $\mathrm{Rp}$ & $\mathrm{B}$ \\
Bibit & $\mathrm{Rp}$ & $\mathrm{C}$ \\
Pakan & $\mathrm{Rp}$ & $\mathrm{D}$ \\
Obat - obatan dan Vitamin & $\mathrm{Rp}$ & $\mathrm{E}$ \\
$\begin{array}{l}\text { TK Luar Keluarga } \\
\text { Lainnya }\end{array}$ & & $\mathrm{F}$ \\
Total Biaya Tunai & $\mathrm{Rp}$ & $\mathrm{G}+\mathrm{C}+\mathrm{D}+$ \\
& & $\mathrm{E}+\mathrm{F}$ \\
Biaya Diperhitungkan & & $\mathrm{H}$ \\
TK Dalam Keluarga & $\mathrm{Rp}$ & $\mathrm{I}$ \\
$\begin{array}{l}\text { Penyusutan Kandang dan } \\
\text { Peralatan }\end{array}$ & $\mathrm{Rp}$ & $\mathrm{J}$ \\
Lainnya & & $\mathrm{K}=$ \\
Total Biaya Diperhitungkan & $\mathrm{Rp}$ & $\mathrm{H}+\mathrm{I}+\mathrm{J}$ \\
Total Harga Pokok Produksi & & $\mathrm{L}=\mathrm{G}+\mathrm{K}$ \\
Harga Pokok Produksi & $\mathrm{Rp} / \mathrm{kg}$ & $\mathrm{L} / \mathrm{A}$ \\
\hline Sumber : Sumodiningrat dan Iswara (1993) & &
\end{tabular}

Metode analisis deskriptif kualitatif digunakan untuk menganalisis bagaimana saluran pemasaran dan lembaga pemasaran apa saja yang terlibat dalam kegiatan pemasaran kambing saburai anggota KPP Saburai Mandiri. Metode analisis deskriptif kualitatif juga digunakan untuk menganalisis peran dan pemanfaatan berbagai jasa layanan penunjang dalam kegiatan usaha ternak kambing saburai anggota KPP Saburai Mandiri yang tersedia di lokasi usaha.

Metode analisis deskriptif kualitatif digunakan untuk menganalisis peran KPP Saburai Mandiri dalam pengadaan sarana produksi dan kegiatan pemasaran kambing saburai. Metode analisis deskriptif kuantitatif digunakan untuk menganalisis kontribusi manfaat ekonomi KPP Saburai Mandiri terhadap pendapatan rumah tangga. Merujuk Nurfitasary, Lestari, dan Suryani (2018), kontribusi manfaat ekonomi koperasi terhadap pendapatan rumah tangga dihitung menggunakan rumus sebagai berikut :

$\mathrm{KMEK}=\left(\mathrm{MEK}_{\text {tunai }} / \mathrm{Prt}\right) \times 100 \%$

keterangan :

$\begin{array}{ll}\text { KMEK } & \text { kontribusi manfaat ekonomi } \\ & \text { koperasi terhadap pendapatan } \\ & \text { rumah tangga } \\ \text { MEK }_{\text {tunai }} & =\text { manfaat ekonomi koperasi tunai } \\ \text { Prt } & =\text { pendapatan rumah tangga }\end{array}$

\section{HASIL DAN PEMBAHASAN}

\section{KPP Saburai Mandiri}

KPP Saburai Mandiri didirikan pada tanggal 23 Februari 2017 yang dipelopori para peternak kambing saburai dan didampingi atau dibina oleh Kantor Perwakilan Bank Indonesia Provinsi Lampung dan dinas terkait. KPP Saburai Mandiri berdiri berdasarkan Surat Keputusan Menteri Koperasi dan Usaha Kecil Menengah Republik Indonesia dengan Badan Hukum Nomor 004478/BH/M.KUKM.2/6/17. Saat ini, KPP Saburai Mandiri telah memiliki 40 anggota dari 14 kelompok tani yang berasal dari empat kecamatan, yaitu Kecamatan Gisting, Sumberejo, Kota Agung Timur, dan Ulu Belu. KPP Saburai Mandiri memiliki 5 unit usaha, yaitu unit usaha permodalan, unit usaha pembibitan, unit usaha produk turunan, unit usaha pemasaran, dan unit usaha sarana produksi usaha ternak.

\section{Karakteristik Responden}

Seluruh responden peternak kambing saburai anggota KPP Saburai Mandiri berada pada usia produktif. Peternak responden mayoritas berada pada rentang usia 41-51 tahun $(50,00 \%)$ dengan pendidikan setara atau sudah melampaui pendidikan dasar dan memiliki pekerjaan utama sebagai petani $(70,00 \%)$. Rentang pengalaman usaha ternak kambing terbanyak berkisar antara 7-12 tahun (52,50\%) dengan lama keanggotaan koperasi adalah 2 tahun $(80,00 \%)$. Jumlah tanggungan keluarga peternak adalah 1-4 orang. Berdasarkan kepemilikan kambing saburai, ratarata kambing saburai yang dimiliki peternak sebanyak 7 ekor dengan luas kandang rata-rata $33,26 \mathrm{~m}^{2}$.

\section{Pengadaan Sarana Produksi Usaha Ternak Kambing Saburai}

Sarana produksi pada usaha ternak kambing saburai terdiri dari kandang, pakan, bibit, obatobatan dan vitamin, peralatan, dan tenaga kerja. Sistem pengadaan sarana produksi usaha ternak kambing saburai anggota KPP Saburai Mandiri dapat dikatakan sangat baik dengan tingkat ketepatan sebesar 83,96 persen. Tingkat ketepatan tertinggi adalah dalam pengadaan dan penggunaan bibit kambing saburai dengan pesentase sebesar 96,67 persen, sedangkan tingkat ketepatan terendah adalah dalam pengadaan dan penggunaan tenaga kerja usaha ternak kambing saburai dengan persentase hanya sebesar 63,33 persen. 
Tabel 3. Perhitungan tingkat ketepatan pengadaan sarana produksi usaha ternak kambing saburai anggota KPP Saburai Mandiri tahun $2018-2019$

\begin{tabular}{lccc}
\hline Sarana Produksi & $\begin{array}{c}\text { Total Bobot } \\
\text { Diperoleh }\end{array}$ & $\begin{array}{c}\text { Total Bobot } \\
\text { Maksimal }\end{array}$ & $\begin{array}{c}\text { Tingkat } \\
\text { Ketepatan }(\%)\end{array}$ \\
\hline Kandang & 213 & 240 & 88,75 \\
Pakan & 181 & 240 & 75,42 \\
Bibit & 232 & 240 & 96,67 \\
Obat - obatan & 231 & 240 & 96,25 \\
dan Vitamin & 200 & 240 & 83,33 \\
Peralatan & 251 & 240 & 63,33 \\
Tenaga Kerja & 1.209 & 1.440 & 83,96 \\
\hline \multicolumn{1}{c}{ Total } & & & \\
\hline
\end{tabular}

Oleh karena itu, dapat dikatakan bahwa sistem pengadaan sarana produksi usaha ternak kambing saburai anggota KPP Saburai Mandiri telah sesuai dengan kriteria 6 tepat. Perhitungan tingkat ketepatan pengadaan sarana produksi usaha ternak kambing saburai anggota KPP Saburai Mandari dapat dilihat pada Tabel 3.

\section{Analisis Pendapatan Usaha Ternak Kambing Saburai}

Hasil produksi kambing saburai adalah 493,58 kg per tahun. Penjualan kambing saburai dibagi menjadi dua, yaitu penjualan dalam bentuk bibit dan kambing potong hidup. Perhitungan harga jual kambing saburai ditentukan berdasarkan berat kambing, yaitu Rp80.000,00 - Rp100.000,00 per kg untuk bibit dan Rp60.000,00 - Rp80.000,00 per $\mathrm{kg}$ untuk kambing potong hidup. Hasil analisis pendapatan usaha ternak kambing saburai anggota KPP Saburai Mandiri dapat dilihat pada Tabel 4.

Berdasarkan data pada Tabel 4, total penerimaan usaha ternak kambing saburai anggota KPP Saburai Mandiri sebesar Rp38.148.262,49 per tahun. Terdiri dari penerimaan tunai sebesar Rp18.894.567,25 per tahun dan penerimaan diperhitungkan sebesar Rp19.253.695,24 per tahun. Biaya produksi yang dikeluarkan dalam usaha ternak kambing saburai sebesar Rp15.584.283,28 per tahun. Terdiri dari biaya tunai sebesar Rp4.945.317,98 per tahun dan biaya diperhitungkan sebesar Rp10.638.965,30 per tahun, sehingga diperoleh pendapatan atas biaya total usaha ternak kambing saburai anggota KPP Saburai Mandiri sebesar Rp22.563.979,21 per tahun. Berdasarkan hasil analisis pendapatan tersebut, dapat dikatakan bahwa usaha ternak kambing saburai anggota KPP Saburai Mandiri telah menguntungkan dan layak dijalankan.
Hasil penelitian ini sejalan dengan Bangun, Sebayang, Salmiah (2013) yang menganalisis mengenai produksi dan pendapatan usaha ternak kambing pedaging sistem kandang. Pada penelitian tersebut menyatakan usaha ternak kambing pedaging sistem kandang memberikan keuntungan dengan rata - rata pendapatan usaha sebesar Rp7.321.447,00/peternak atau sebesar Rp324.765/ekor.

\section{Analisis Harga Pokok Produksi Kambing Saburai}

Analisis harga pokok produksi kambing saburai anggota KPP Saburai Mandiri dihitung berdasarkan total produksi dan total biaya usaha ternak kambing saburai dalam satu tahun. Metode yang digunakan untuk penentuan harga pokok produksi adalah metode atas biaya total (full costing). Perhitungan harga pokok produksi kambing saburai anggota KPP Saburai Mandiri dapat dilihat pada Tabel 5.

Tabel 4. Pendapatan usaha ternak kambing saburai anggota KPP Saburai Mandiri tahun $2018-2019$

\begin{tabular}{lr}
\hline \multicolumn{1}{c}{ Uraian } & Nilai (Rp/tahun) \\
\hline Penerimaan & \\
Penerimaan Tunai & \\
Penjualan Bibit Kambing Saburai & $2.453 .881,07$ \\
Penjualan Kambing Saburai Potong & $15.214 .384,77$ \\
Penjualan Kotoran Kambing Saburai & $853.329,98$ \\
Penjualan Pupuk Padat 10 kg & $41.474,31$ \\
Penjualan Pupuk Padat 50 kg & $284.413,56$ \\
Penjualan Pupuk Cair & $7.083,55$ \\
Penerimaan Diperhitungkan & \\
Pertambahan Bobot dan Jumlah Anakan & $19.253 .695,24$ \\
Total Penerimaan & $38.148 .262,49$ \\
Biaya Produksi & \\
Biaya Tunai & \\
Bibit & $2.960 .041,91$ \\
Pakan & $874.309,99$ \\
Obat - obatan dan Vitamin & $137.369,54$ \\
Pembelian Peralatan & $9.281,63$ \\
TK Luar Keluarga (TKLK) & $417.003,64$ \\
Transportasi & $309.599,75$ \\
Pembuatan Pupuk & $169.747,75$ \\
Listrik & $63.406,27$ \\
Pajak & $4.557,50$ \\
Total Biaya Tunai & $4.945 .317,98$ \\
Biaya Diperhitungkan & \\
TK Dalam Keluarga (TKDK) & $9.644 .666,59$ \\
Penyusutan Kandang dan Peralatan & $10.638 .965,30$ \\
Total Biaya Diperhitungkan & $15.584 .283,28$ \\
Total Biaya & \\
Pendapatan & $33.202 .944,51$ \\
Pendapatan Atas Biaya Tunai & $22.563 .979,21$ \\
Pendapatan Atas Biaya Total & \\
\hline & \\
\hline & \\
&
\end{tabular}


Tabel 5. Harga pokok produksi kambing saburai anggota KPP Saburai Mandiri tahun $2018-2019$

\begin{tabular}{lcr}
\hline \multicolumn{1}{c}{ Uraian } & Satuan & \multicolumn{1}{c}{ Nilai } \\
\hline Total Produksi & $\mathrm{Kg}$ & 493,58 \\
Biaya Produksi & & \\
Biaya Tunai & $\mathrm{Rp}$ & $2.960 .041,91$ \\
Bibit & $\mathrm{Rp}$ & $874.309,99$ \\
Pakan & $\mathrm{Rp}$ & $137.369,54$ \\
Obat-obatan dan Vitamin & $\mathrm{Rp}$ & $18.425,00$ \\
Pembelian Peralatan & $\mathrm{Rp}$ & $417.003,64$ \\
TK Luar Keluarga (TKLK) & $\mathrm{Rp}$ & $309.599,75$ \\
Transportasi & $\mathrm{Rp}$ & $63.406,27$ \\
Listrik & $\mathrm{Rp}$ & $4.557,50$ \\
Pajak & $\mathrm{Rp}$ & $4.784 .713,60$ \\
Total Biaya Tunai & & \\
Biaya Diperhitungkan & $\mathrm{Rp}$ & $9.644 .666,59$ \\
TK Dalam Keluarga (TKDK) & $\mathrm{Rp}$ & $994.298,71$ \\
Penyusutan kandang dan alat & $\mathrm{Rp}$ & $10.638 .965,30$ \\
Total Biaya Diperhitungkan & $\mathrm{Rp}$ & $15.423 .678,90$ \\
Total Harga Pokok Produksi & $\mathrm{Rp}$ \\
Harga Pokok Produksi & $\left.\mathrm{Rp} / \mathrm{kg}^{*}\right)$ & $31.248,68$ \\
\hline *) kg bobot hidup & &
\end{tabular}

Berdasarkan data pada Tabel 5, harga pokok produksi kambing saburai anggota KPP Saburai Mandiri dengan metode atas biaya total atau full costing adalah sebesar Rp31.248,68 per kilogram. Hasil perhitungan tersebut menunjukkan perbedaan atau selisih antara harga pokok produksi dengan harga jual kambing saburai, yaitu sebesar Rp61.525,65 per kilogram terhadap harga jual bibit kambing saburai dan Rp38.402,29 per kilogram terhadap harga jual kambing saburai potong hidup.

Berdasarkan hasil perhitungan tersebut, dapat dikatakan bahwa usaha ternak kambing saburai anggota KPP Saburai Mandiri telah berjalan dengan baik. Hasil penelitian ini sesuai dengan penelitian Hadi, Ismono, dan Yanfika (2015) dimana peternak memperoleh laba karena harga jual per kg lebih tinggi dibandingkan harga pokok produksi per $\mathrm{kg}$.

\section{Saluran Pemasaran}

Saluran pemasaran dalam usaha ternak kambing saburai anggota KPP Saburai Mandiri terbagi menjadi saluran pemasaran bibit kambing saburai dan saluran pemasaran kambing saburai potong hidup yang masing-masing memiliki empat saluran pemasaran. Skema saluran pemasaran kambing saburai anggota KPP Saburai Mandiri dapat dilihat pada Gambar 1 dan Gambar 2.

Pada Gambar 1 dapat dilihat saluran pemasaran pertama bibit kambing saburai, yaitu peternak produsen melakukan penjualan melalui KPP
Saburai Mandiri disalurkan kepada pemerintah dan dari pemerintah disalurkan kepada peternak lain sebagai bantuan. Pada saluran kedua, peternak produsen melakukan penjualan melalui KPP Saburai Mandiri dan langsung disalurkan kepada peternak lain. Saluran pemasaran ketiga, peternak produsen melakukan penjualan kepada tengkulak yang kemudian langsung dijual kepada peternak lain dan pada saluran pemasaran keempat, peternak produsen langsung menjual bibit kambing saburai kepada peternak lain tanpa melalui perantara.

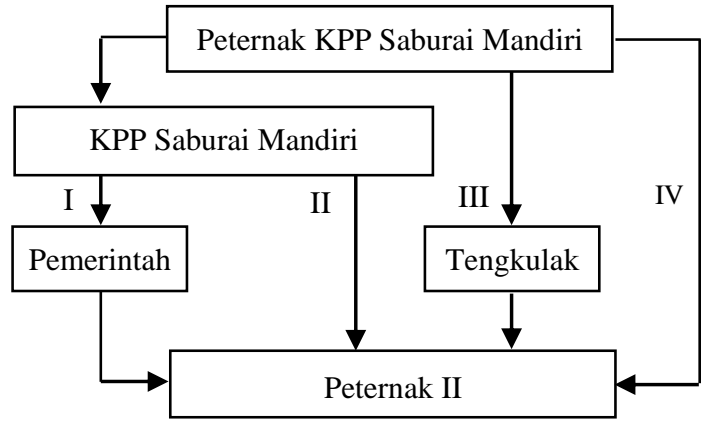

Gambar 1. Saluran pemasaran bibit kambing saburai anggota KPP Saburai Mandiri tahun 2018 - 2019

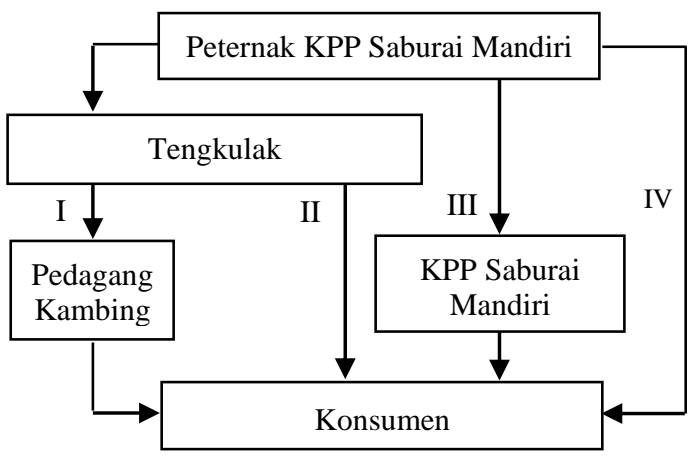

Gambar 2. Saluran pemasaran kambing saburai potong hidup anggota KPP Saburai Mandiri tahun 2018 - 2019

Pada Gambar 2 dapat dilihat saluran pemasaran pertama kambing saburai potong hidup, yaitu peternak produsen melakukan penjualan melalui tengkulak disalurkan kepada pedagang kambing dan kemudian disalurkan kepada konsumen. Saluran pemasaran kedua, peternak produsen menjual kambing saburai potong kepada tengkulak dan dari tengkulak langsung disalurkan kepada konsumen. Saluran pemasaran ketiga, peternak produsen menjual kambing saburai potong melalui KPP Saburai Mandiri yang kemudian disalurkan kepada konsumen dan pada saluran keempat, peternak produsen langsung melakukan penjualan kepada konsumen tanpa melalui perantara apapun. 
Tabel 6. Ketersediaan dan pemanfaatan jasa layanan penunjang oleh peternak kambing saburai anggota KPP Saburai Mandiri tahun $2018-2019$

\begin{tabular}{lc}
\hline \multicolumn{1}{c}{$\begin{array}{c}\text { Jasa Layanan Yang } \\
\text { Tersedia }\end{array}$} & $\begin{array}{r}\text { Tingkat Pemanfaatan } \\
(\%)\end{array}$ \\
\hline Lembaga Keuangan (Bank) & 22,50 \\
Lembaga Penyuluhan & 100,00 \\
Lembaga Penelitian & 0,00 \\
Kebijakan Pemerintah & 100,00 \\
Kelompok Tani/Ternak & 100,00 \\
Sarana Transportasi & 100,00 \\
Teknologi Informasi dan & 100,00 \\
Komunikasi & 100,00 \\
Pasar & \\
\hline
\end{tabular}

Hasil penelitian ini berbeda dengan Alamsyah, Taslim, dan Fitriani (2015) yang menganalisis mengenai saluran dan margin pemasaran sapu potong. Pada penelitian tersebut diperoleh bahwa hanya terdapat tiga saluran pemasaran sapi potong di Pasar Hewan Tanjungsari.

\section{Jasa Layanan Penunjang}

Jasa layanan penunjang menjadi salah satu faktor penting dalam kegiatan usaha ternak kambing saburai anggota KPP Saburai Mandiri. Ketersediaan dan pemanfaatan jasa layanan penunjang oleh peternak kambing saburai anggota KPP Saburai Mandiri dapat dilihat pada Tabel 6.

Pada Tabel 6 dapat dilihat bahwa terdapat delapan jasa layanan penunjang yang tersedia di lokasi usaha ternak kambing saburai anggota KPP Saburai Mandiri, namun belum seluruhnya dimanfaatkan. Jasa layanan penunjang yang telah dimanfaatkan oleh sebagian atau seluruh anggota koperasi adalah lembaga keuangan (bank), lembaga penyuluhan, kebijakan pemerintah, kelompok tani/ternak, sarana transportasi, teknologi informasi dan komunikasi, dan pasar. Sedangkan, jasa layanan penunjang yang belum dimanfaatkan adalah lembaga penelitian. Lembaga keuangan (bank) dimanfaatkan oleh peternak kambing saburai anggota KPP Saburai Mandiri untuk memperoleh pinjaman modal dengan bunga yang cukup rendah.

Lembaga penyuluhan dimanfaatkan oleh peternak untuk mendapatkan penyuluhan dan/atau pelatihan mengenai usaha yang dijalankan. Kebijakan pemerintah yang menunjang usaha ternak kambing saburai anggota KPP Saburai Mandiri adalah penyelenggaraan Bazar Hewan Qurban yang diselenggarakan setiap tahun ketika mendekati
Hari Raya Idul Adha. Peran kelompok tani dalam usaha ternak kambing saburai anggota KPP Saburai Mandiri adalah dalam penyediaan alat pembuatan pupuk organik (kompos) dan alat pencacah rumput yang berasal dari bantuan pemerintah dan dapat digunakan oleh seluruh anggota kelompok tani.

Sarana transportasi berperan dalam usaha ternak kambing saburai anggota KPP Saburai Mandiri, seperti halnya kendaraan dan juga jalan yang memadai, sehingga memudahkan peternak menjalankan kegiatan dalam usaha ternak kambing saburai. Teknologi informasi dan komunikasi digunakan oleh peternak kambing saburai anggota KPP Saburai Mandiri untuk memperoleh informasi mengenai kondisi dan situasi pasar. Selain itu, teknologi informasi dan komunikasi juga memudahkan peternak untuk berkomunikasi dengan calon pembeli atau konsumen. Selanjutnya, jasa layanan penunjang terakhir yang tersedia di lokasi usaha ternak kambing saburai anggota KPP Saburai Mandiri adalah pasar yang memudahkan peternak dalam memperoleh input dan memasarkan output dari usaha ternak kambing saburai yang dijalankan.

Hasil penelitian ini sedikit berbeda dengan Satiti, Lestari, dan Suryani (2017) mengenai sistem agribisnis dan kemitraan usaha penggemukan sapi potong Koperasi Gunung Madu (KGM). Lembaga jasa layanan penunjang dalam agribisnis penggemukan sapi potong KGM adalah lembaga penyuluhan, sarana transportasi, sistem informasi dan komunikasi, dan kebijakan pemerintah.

\section{Peran KPP Saburai Mandiri}

Pada pengadaan sarana produksi usaha ternak kambing saburai, KPP Saburai Mandiri berperan dalam penyediaan bibit kambing saburai secara kredit melalui unit usaha permodalan, penyediaan bibit untuk proses pembiakan melalui unit usaha pembibitan, dan penyediaan moleses atau tetes tebu melalui unit usaha sarana produksi usaha ternak (sapronak). Pada kegiatan usahanya, peran KPP Saburai Mandiri dilihat melalui kontribusi manfaat ekonomi terhadap pendapatan rumah tangga. Kontribusi manfaat ekonomi koperasi terhadap pendapatan rumah tangga merupakan persentase manfaat ekonomi koperasi tunai yang diterima oleh anggota terhadap pendapatan rumah tangga anggota koperasi. Pada Tabel 7 disajikan perhitungan kontribusi manfaat ekonomi koperasi terhadap pendapatan rumah tangga peternak kambing saburai anggota KPP Saburai Mandiri. 
Tabel 7. Kontribusi manfaat ekonomi koperasi terhadap pendapatan rumah tangga anggota KPP Saburai Mandiri tahun $2018-2019$

\begin{tabular}{lcc}
\hline \multicolumn{1}{c}{ Jenis Pendapatan } & $\begin{array}{c}\text { Nilai } \\
\text { (Rp/tahun) }\end{array}$ & $\begin{array}{c}\text { Kontribusi } \\
(\%)\end{array}$ \\
\hline $\begin{array}{l}\text { Pendapatan } \text { on farm usaha } \\
\text { ternak kambing saburai }\end{array}$ & $33.202 .944,51$ & 37,45 \\
$\begin{array}{l}\text { Pendapatan on farm usaha } \\
\text { ternak kambing } \text { non saburai }\end{array}$ & $28.839 .912,37$ & 32,53 \\
$\begin{array}{l}\text { Pendapatan } \text { on farm selain } \\
\text { usaha ternak kambing }\end{array}$ & $21.193 .750,00$ & 23,90 \\
$\begin{array}{l}\text { Pendapatan luar usaha tani } \\
\text { (off farm) }\end{array}$ & $3.597 .500,00$ & 4,06 \\
$\begin{array}{l}\text { Pendapatan luar pertanian } \\
\text { (non farm) }\end{array}$ & $1.810 .000,00$ & 2,04 \\
$\begin{array}{l}\text { Manfaat ekonomi koperasi } \\
\text { tunai }\end{array}$ & $16.010,43$ & 0,02 \\
\hline \multicolumn{1}{c}{ Total } & $88.660 .117,31$ & 100,00 \\
\hline
\end{tabular}

Rata-rata pendapatan rumah tangga peternak kambing saburai anggota KPP Saburai Mandiri sebesar Rp88.660.117,31 per tahun. Pendapatan tersebut berasal dari pendapatan on farm usaha ternak kambing saburai, pendapatan on farm usaha ternak kambing non saburai, pendapatan on farm selain usaha ternak kambing, pendapatan luar usahatani (off farm), pendapatan luar bidang pertanian (non farm), dan pendapatan yang diperoleh dari manfaat ekonomi koperasi tunai yang diterima oleh peternak kambing saburai sebagai anggota koperasi.

Kontribusi manfaat ekonomi KPP Saburai Mandiri terhadap pendapatan rumah tangga anggotanya adalah sebesar 0,02 persen. Artinya, kontribusi manfaat ekonomi KPP Saburai Mandiri terhadap pendapatan rumah tangga anggota koperasi dapat dikatakan masih sangat rendah. Kontribusi manfaat ekonomi koperasi yang masih sangat rendah tersebut, dikarenakan manfaat ekonomi koperasi tunai yang diterima oleh anggota koperasi hanya berasal dari pembagian sisa hasil usaha saja yang mana masih sangat rendah, yaitu sebesar Rp16.010,43 per tahun.

Hasil penelitian ini sejalan dengan Sijabat, Widjaja, dan Adawiyah (2018) mengenai analisis kinerja pelayanan KUD Usaha Bersama kepada anggota dan strategi pengembangannya. Hasil penelitian tersebut menunjukan bahwa kontribusi manfaat ekonomi koperasi terhadap pendapatan rumah tangga anggota koperasi masih sangat rendah, yaitu hanya sebesar 0,25 persen.

Pada kegiatan pemasaran kambing saburai anggota koperasi, KPP Saburai Mandiri melalui unit usaha pemasaran berperan cukup baik, khususnya dalam pemasaran bibit kambing saburai. Peran KPP Saburai Mandiri dalam kegiatan pemasaran kambing saburai dapat dilihat dari besarnya volume penjualan kambing saburai yang melalui koperasi, yaitu dalam pemasaran bibit kambing saburai sebanyak $864,00 \mathrm{~kg}$ atau setara dengan 81,66 persen dari total seluruh volume penjualan bibit kambing saburai. Pada pemasaran kambing saburai potong, volume penjualan yang melalui KPP Saburai Mandiri sebanyak 636,75 $\mathrm{kg}$ atau hanya 7,29 persen dari total seluruh volume penjualan kambing saburai potong anggota koperasi.

\section{KESIMPULAN}

Pengadaan sarana produksi dalam kegiatan usaha ternak kambing saburai anggota KPP Saburai Mandiri telah tepat dengan tingkat ketepatan sebesar 83,96 persen. Usaha ternak kambing saburai anggota KPP Saburai Mandiri telah menguntungkan dan layak untuk dijalankan dengan rata-rata pendapatan Rp22.563.979,21 per tahun. Harga pokok produksi kambing saburai sebesar Rp31.248,68 per kg. Saluran pemasaran kambing saburai anggota KPP Saburai Mandiri terbagi menjadi dua, yaitu saluran pemasaran bibit kambing saburai dan kambing saburai potong hidup yang masing-masing memiliki empat saluran pemasaran. Jasa layanan penunjang dalam sistem agribisnis usaha ternak kambing saburai anggota KPP Saburai Mandiri adalah lembaga keuangan (bank), lembaga penyuluhan, kebijakan pemerintah, kelompok tani/ternak, sarana transportasi, teknologi informasi dan komunikasi, dan pasar. Peran KPP Saburai Mandiri dalam sistem agribisnis kambing saburai sudah cukup baik.

\section{DAFTAR PUSTAKA}

Alamsyah AF, Taslim, dan Fitriani A. 2015. Analisis saluran dan margin pemasaran sapi potong di Pasar Hewan Tanjungsari. Students $\begin{array}{llll}\text { E-Journals, } & 4 & \text { (2): } & \text { 1-12. }\end{array}$ http://jurnal.unpad.ac.id/ejournal/article/view/ 6251. [23 Maret 2020].

Arinkunto S. 2012. Prosedur Penelitian. Rineka Cipta. Jakarta.

Bangun ES, Sebayang T, dan Salmiah. 2013. Analisis produksi dan pendapatan usaha ternak kambing pedaging sistem kandang (Kasus: Kelurahan Tanah Enam Ratus, Kecamatan Medan Marelan, Kota Medan). Journal On Social Economic Of Agriculture 
And Agribusiness, 2 (7) : 1-15. https://jurnal.usu.ac.id/index.php/ceress/article /view/7910/3377. [23 Maret 2020].

Dinas Peternakan Kabupaten Tanggamus. 2015. Persentase Populasi Kambing Saburai. Disnak Tanggamus. Dinas Peternakan Kabupaten Tanggmus. Kota Agung.

Ditjen [Direktorat Jendral] Peternakan dan Kesehatan Hewan. 2019. Statistik Peternakan dan Kesehatan Hewan 2019. Kementerian Pertanian. http://ditjenpkh. pertanian.go.id/buku-statistik-peternakan-dankesehatan-hewan-tahun-2019. [25 Februari 2020].

Hadi AF, Ismono RH, dan Yanfika H. 2015. Analisis harga pokok produksi, laba usaha, dan permintaan ayam ras pedaging probiotik di Kota Metro. Jurnal Ilmu Ilmu Agribisnis, 7 (1): 91-98. https://jurnal.fp.unila.ac.id/index.php/JIA/artic le/view/1047/952. [28 Januari 2020].

Nurfitasary L, Lestari DAH, dan Suryani A. 2018. Peran Koperasi Pertanian (KOPTAN) Mitra Subur dalam peningkatan pendapatan dan kesejahteraan petani padi di Kecamatan Gunung Sugih Kabupaten Lampung Tengah. Skripsi. Fakultas Pertanian Universitas Lampung. Bandar Lampung.

Peraturan Menteri Pertanian Nomor
57/Permentan/OT.140/10/2006 tentang Pedoman Pembibitan Kambing dan Domba yang Baik (Good Breeding Practice).

Peraturan Menteri Pertanian Nomor 19/Permentan/OT.140/3/2012 tentang Persyaratan Mutu Benih, Bibit Ternak, dan Sumber Daya Genetik Hewan.

Riduwan. 2004. Belajar Mudah Penelitian untuk Guru-Karyawan dan Peneliti Pemula. Alfabeta. Bandung.

Satiti R, Lestari DAH, dan Suryani A. 2017. Analisis sistem agribisnis dan kemitraan usaha penggemukan sapi potong di Koperasi Gunung Madu. Jurnal Ilmu Ilmu Agribisnis, 5 (4): 344-351. https://jurnal.fp.unila.ac.id/index.php/JIA/artic le/view/1743/1546. [18 Februari 2019].

Sijabat WV, Widjaja S, dan Adawiyah R. 2018. Analisis kinerja pelayan koperasi kepada anggota dan strategi pengembangannya (studi kasus KUD Usaha Bersama di Kabupaten Lampung Utara). Jurnal Ilmu Ilmu Agribisnis, $6 \quad$ (1) : 87-94. http://jurnal.fp.unila.ac.id/index.php/JIA/ article/view/2503/2187. [15 Februari 2019].

Soekartawi. 2000. Pengantar Agroindustri. PT Raja Grafindo Persada. Jakarta.

Sumodiningrat G dan Iswara LA. 1993. Ekonomi Produksi. Universitas Terbuka. Jakarta. 